\title{
Effect of modified atmosphere package on apricot fruit storability
}

\author{
Ezzat, A. ${ }^{1,2}$ \\ ${ }^{1}$ Institute of Horticulture, University of Debrecen, Debrecen, Hungary \\ ${ }^{2}$ Department of Horticulture, Faculty of Agriculture, Kafrelsheikh University, Kafr El-Shaikh, Egypt \\ Author for correspondence: ezz.deb12@gmail.com
}

\begin{abstract}
Summary: The aim of this work was to study the effect of modified atmosphere package (MAP) on apricot storability. Apricots (Prunus armeniaca L.) cultivar Jumbo cot were harvested at commercial ripening stage. The fruits were treated with different storage treatments as following: i) control storage for 13 days at $1{ }^{\circ} \mathrm{C}$, ii) stored fruit at $1{ }^{\circ} \mathrm{C}$ for 10 days then 3 days at shelf at $25^{\circ} \mathrm{C}$, iii) fruit stored in MAP at $1{ }^{\circ} \mathrm{C}$ for 13 days and iv) fruit stored in MAP at $1{ }^{\circ} \mathrm{C}$ for 10 days then 3 days at shelf at $25^{\circ} \mathrm{C}$. Data showed the positive effect of MAP in keeping the apricot fruit for long time with better quality than the control fruit. MAP showed positive effect by recording the lowest fruit weight loss, the highest firmness and lowest chilling injury and fruit decay.
\end{abstract}

Ezzat, A. (2018): Effect of modified atmosphere package on apricot fruit storability. International Journal of Horticultural Science 24(34): 30-32. https://ojs.lib.unideb.hu/IJHS/article/view/2645

Key words: apricot, MAP, storability

\section{Introduction}

Apricot is a climacteric stone fruit that has a limited postharvest life. The fruits remain fresh only for 2-4 weeks after harvest if they stored at $0^{\circ} \mathrm{C}$ depending on cultivar (Stanley 1991). Most apricot cultivars show chilling injury symptoms and a high percentage of fruit decay during storage (Stanley 1991, Holb et al., 2006, 2011ab). During storage, most apricot fruits lose their physical and chemical qualities e.g. fruit firmness, increased fruit acidity and reduction in soluble solid content (Stanley 1991; Ezzat et al. 2012). Modified atmosphere packaging (MAP) along with refrigeration of different food products has been shown to extend postharvest life of the fruit (Singh et al., 2010). The benefits of MAP in extending shelf-life of many fruits and vegetables have been extensively studied (Lee et al., 1995; Chonhenchob et al., 2007). In addition, a few studies investigated the effects of controlled atmosphere storage on the quality of different apricot cultivars (Wankier et al., 1970; Claypool and Pangborn, 1973; Pretel et al., 1999). The aim of this work to study the effect of modified atmosphere package and controlled atmosphere storage on apricot storability.

\section{Materials and methods}

100 fruit of $P$. armeniaca (cv. Jumbo cot) were selected from the storage house at $1^{\circ} \mathrm{C}$ (fruit were harvested 3 days earlier) for all treatments. Treatments were:

- control (fruit stored for 13 days at $1{ }^{\circ} \mathrm{C}$ ),

- control + shelf-life (fruit stored for 10 days at $1{ }^{\circ} \mathrm{C}+3$ days at $\left.25^{\circ} \mathrm{C}\right)$,

- $\operatorname{MAP}\left(13\right.$ days MAP at $\left.1{ }^{\circ} \mathrm{C}\right)$,

- MAP + shelf-life $\left(10\right.$ days MAP at $1{ }^{\circ} \mathrm{C}+3$ days at $\left.25^{\circ} \mathrm{C}\right)$.

All fruits were investigated physically by measuring the weight loss, fruit firmness, chilling injuries, and fruit decay.
Weight loss: percentage loss of the initial weight using a digital balance (BL S3102 Precision Balance, Bel Engineering, Italy). Fruit firmness was measured with a fruit penetrometer (model FT011; Facchini Francesco Srl, Brescia, Italy).

Chilling injury (CI) of apricot fruit was measured by detecting flesh browning. The percentage of CI was visually detected. The extent of flesh browning was detected according to the study of Ezzat et al. (2017b). Briefly, (0) no CI; (1) CI <25\%; (2) CI between 25 and 50\%; (3) CI between $50 \%$ and $75 \%$; (4) CI $\geq 75 \%$ of the cut surface. From this a CI index was calculated as $\Sigma[(\mathrm{CI}$ level $) \times($ number of fruit at the $\mathrm{CI}$ level $)] /(4 \times$ total number of fruit in the treatment). Fruit decay (FD) was detected as the severity of the symptoms according to the study of Wang et al. (2006). Briefly: (0) no FD; (1) FD $\geq 25 \%$; (2) FD between $25 \%$ and $<50 \%$; (3) FD between $50 \%$ and $<75 \%$; and (4) FD $\geq 75 \%$. From this, FD index was calculated as $\Sigma[$ (FD level) $\times$ (number of fruit at the FD level $)] /(4 \times$ total number of fruit in the treatment $)$ according to the study of Ezzat et al. (2017b).

\section{Results and discussion}

Weight loss is one of the basic parameters to determine apricot fruit quality. It was reported that during the storage apricot fruit tend to loss weight (Ezzat et al., 2017a). Data showed the positive effect of MAP on reducing the fruit weight loss, fruit stored in MAP for 13 days showed the lowest fruit weigh loss while fruit of control + shelf-life treatment showed the highest reduction in fruit weight (Figure 1). Apricot showed a trend to keep less weight loss by different treatments like methyl-jasmonate or salicylic acid (Ezzat et al., 2017a). Onursal et al. (2015) showed that MAP showed an effect on reducing the fruit weight loss during storage. 


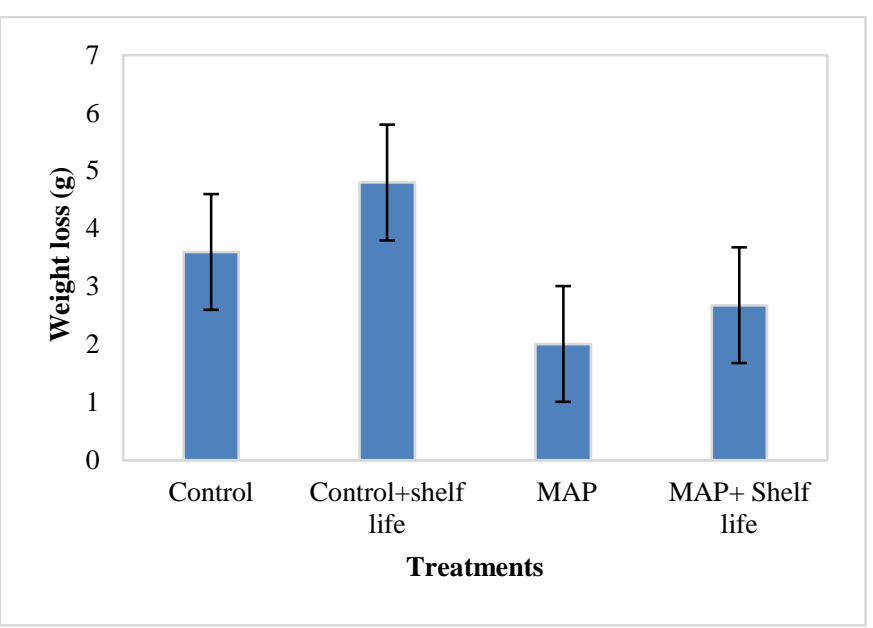

Figure 1. Effect of MAP on apricot weight loss with different treatments: i) control (fruit stored for 13 days at $1{ }^{\circ} \mathrm{C}$ ), ii) control + shelf-life (fruit stored for 10 days at $1{ }^{\circ} \mathrm{C}+3$ days at $\left.25^{\circ} \mathrm{C}\right)$, iii) MAP $\left(13\right.$ days MAP at $\left.1{ }^{\circ} \mathrm{C}\right)$, iv) MAP + shelf-life $\left(10\right.$ days MAP at $1{ }^{\circ} \mathrm{C}+3$ days at $\left.25^{\circ} \mathrm{C}\right)$. Error bars represent the SD values.

Storage period and treatments modified the flesh firmness during storage (Figure 2). Fruit firmness decreased in all the treatments. Amount of decrease in firmness was lower in MAP treatments. Data showed that the unpackage fruit had the significant reduction in firmness in compare to MAP. Data also showed that the firmness reduced in the MAP + shelf-life treatment. While decrease in firmness of unpackaged fruit mainly resulted from water losses (Ezzat et al., 2017a,b), that of packaged apricots was most probably due to fruit ripening and senescence (Pretel et al., 1999).

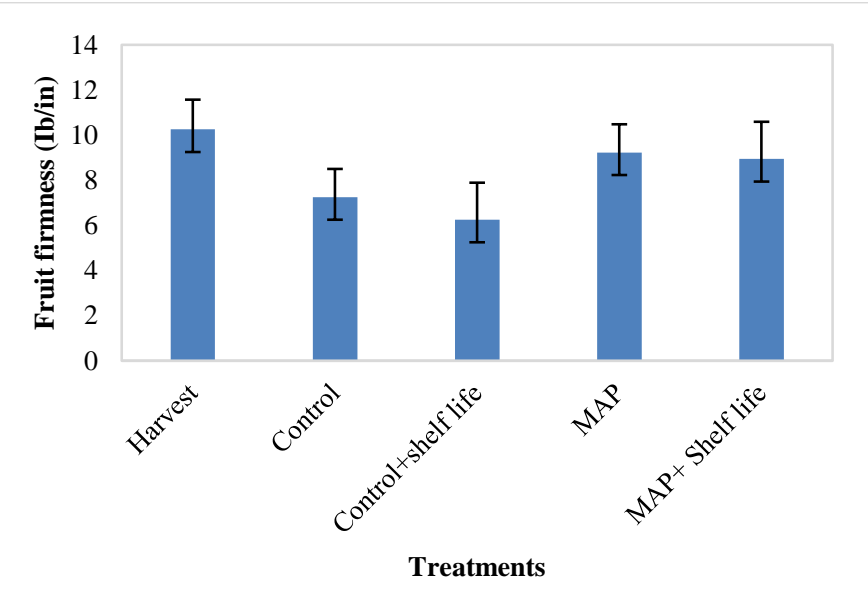

Figure 2. Effect of MAP on apricot fruit firmness with different treatments: i) control (fruit stored for 13 days at $1{ }^{\circ} \mathrm{C}$ ), ii) control + shelf-life (fruit stored for 10 days at $1{ }^{\circ} \mathrm{C}+3$ days at $\left.25^{\circ} \mathrm{C}\right)$, iii) MAP $\left(13\right.$ days MAP at $\left.1{ }^{\circ} \mathrm{C}\right)$, iv) MAP + shelf-life $\left(10\right.$ days MAP at $1{ }^{\circ} \mathrm{C}+3$ days at $\left.25^{\circ} \mathrm{C}\right)$. Error bars represent the SD values.

Data in Figures 3-4 showed the effect of different storage treatment on chilling index and fruit decay. MAP treatment showed the lowest percentage of CI and FD followed by MAP +shelf-life treatment. Ezzat et al. (2017a) indicated that different apricot cultivars showed response by treatment with salicylic acid and/or methyl-jasmonate. Chilling index occurs primarily as the membrane damage which initiates as a cascade of secondary reactions leading to disruption of cell structures (Stanley 1991). Membrane damage can be measured by the electrolyte leakage.

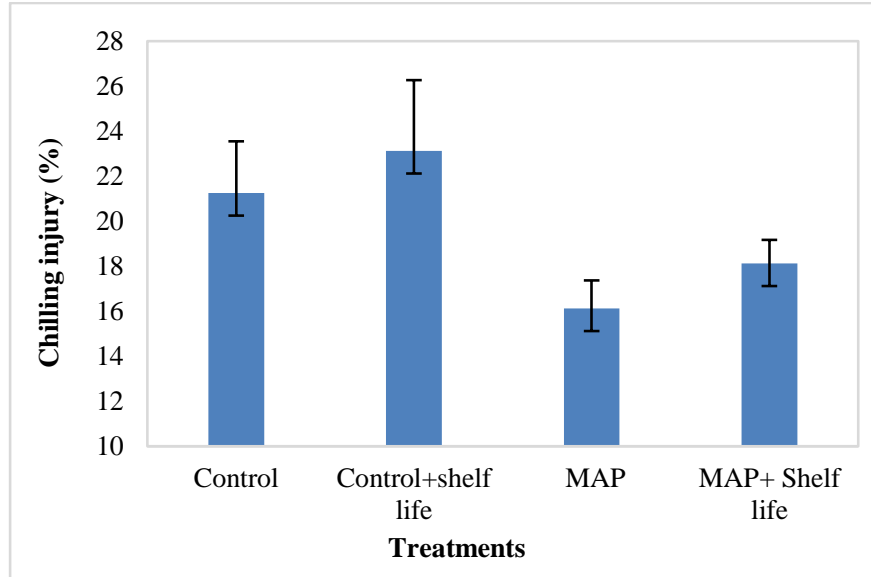

Figure 3. Effect of MAP on apricot chilling injury (\%) with different treatments i) control (fruit stored for 13 days at $1^{\circ} \mathrm{C}$ ), ii) control + shelf-life (fruit stored for 10 days at $1{ }^{\circ} \mathrm{C}+3$ days at $\left.25^{\circ} \mathrm{C}\right)$, iii) MAP $\left(13\right.$ days MAP at $\left.1{ }^{\circ} \mathrm{C}\right)$, iv) MAP + shelf-life $\left(10\right.$ days MAP at $1{ }^{\circ} \mathrm{C}+3$ days at $\left.25^{\circ} \mathrm{C}\right)$. Error bars represent the SD values.

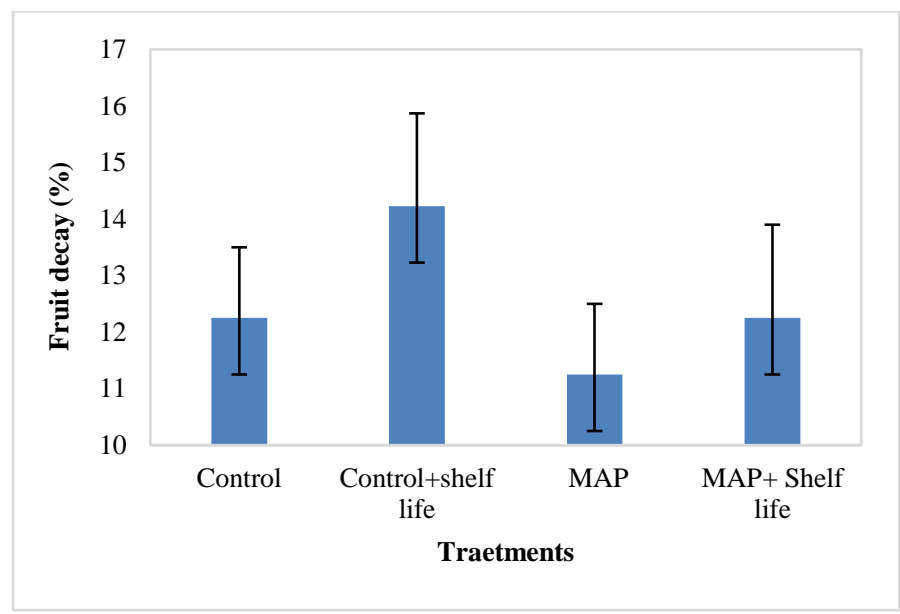

Figure 4. Effect of MAP on apricot fruit decay (\%) with different treatments: i) control (fruit stored for 13 days at $1{ }^{\circ} \mathrm{C}$ ), ii) control + shelf-life (fruit stored for 10 days at $1{ }^{\circ} \mathrm{C}+3$ days at $\left.25^{\circ} \mathrm{C}\right)$, iii) MAP $\left(13\right.$ days MAP at $\left.1{ }^{\circ} \mathrm{C}\right)$, iv) MAP + shelf-life $\left(10\right.$ days MAP at $1{ }^{\circ} \mathrm{C}+3$ days at $\left.25^{\circ} \mathrm{C}\right)$. Error bars represent the SD values.

\section{Conclusions}

The MAP treatment can keep the fruit in a good quality during the storage but further study need to determine how MAP can be applied practically at business level. Fruit can directly packed in MAP then stored in cold or fruit can be stored in cold and then packed into MAP.

\section{References}

Chonhenchob, V., Chantarasomboon, Y., Singh, S. P. (2007): Quality changes of treated fresh-cut tropical fruits in rigid modified atmosphere packaging containers. Packaging Technology and Science, 20(1), 27-37.

Claypool, L. L., Pangborn, R. M. (1973): Influence of controlled atmosphere on quality of canned apricots. Journal of the American Society for Horticultural Science, 97, 636-638. Doi: https://doi.org/10.17660/ActaHortic.2015.1071.17

Ezzat, A., Nyéki, J., Soltész, M., Amriskó, L., Balázs, G. I., Mikita, T., Szabó, Z. (2012): Storability of some apricot varieties as affected by storage period. International Journal of 
Horticultural Science, 18(1), 39-42. Doi:https://doi.org/10.31421/IJHS/18/1/992

Ezzat, A., Ammar, A., Szabó, Z., Holb, I. (2017a): Salicylic acid treatment saves quality and enhances antioxidant properties of apricot fruit. Horticultural Science, 44(2), 73-81.

Ezzat, A., Ammar, A., Szabó, Z., Nyéki, J., Holb, I. J. (2017b): Postharvest treatments with methyl jasmonate and salicylic acid for maintaining physico-chemical characteristics and sensory quality properties of apricot fruit during cold storage and shelf-life. Polish Journal of Food and Nutrition Sciences, 67(2), 159-166.

Holb, I. J., Soltész, M., Nyéki, J., Szabó, Z. (2011a): Incidence of postharvest decays on cultivars of pear, apricot, sour cherry and peach under two storage conditions. International Journal of Horticultural Science, 18(4-5), 63-65. Doi: https://doi.org/10.31421/IJHS/17/4-5/971

Holb, I. J., Soltész, M., Nyéki, J., Szabó, Z. (2011b). Susceptibility of fruit of some plum and apricot cultivars to brown rot. International Journal of Horticultural Science, 17: 5356. DOI: https://doi.org/10.31421/IJHS/17/1-2./945

Holb, I. J., Drén, G., Szabó, Z., Racskó, J., Thurzó, S., Nyéki, J. (2006): Brown rot blossom blight and fruit rot incidences of apricot in two different geographical regions in Hungary. Acta Horticulturae 717, 123-126.

Lee, L., Arul, J., Lencki, R., Castaigne, F. (1995). A review on modified atmosphere packaging and preservation of fresh fruits and vegetables: Physiological basis and practical aspectspart I. Packaging Technology and Science, 8(6), 315-331.

Onursal, C. E., Bayındır, D., Celepaksoy, F., Koyuncu, M. A. (2015): Combined effects of map and postharvest putrescine treatment on storage life and quality of 'Alyanak' apricot. Acta Horticulturae, 1071, 165-172.

Pretel, M. T., Souty, M., Romojaro, F. (2000): Use of passive and active modified atmosphere packaging to prolong the postharvest life of three varieties of apricot (Prunus armeniaca, L.).

Singh, P., Wani, A. A., Goyal, G. K. (2010): Shelf-life extension of fresh ready-to bake pizza by the application of modified atmosphere packaging. Food and Bioprocess Technology. Doi:10.1007/s11947-010-0447-9.

Stanley, D. W. (1991): Biological membrane deterioration and associated quality losses in food tissues. Critical Review of Food Science and Nutrition, 30: 487-553.

Wang, L., Chena, S., Kong, W., Li, S., Archbold, D. (2006): Salicylic acid pretreatment alleviates chilling injury and affects the antioxidant system and heat shock proteins of peaches during cold storage. Postharvest Biology and Technology, 41: 244-251. Wankier, B. N., Salunkhe, D. K., Campbell, W. F. (1970): Effects of controlled atmosphere storage on biochemical changes in apricot and peach fruit. Journal of the American Society for Horticultural Science, 95, 604-609. 